\title{
A study of utilization pattern, efficacy and safety of drugs prescribed for opportunistic infections in Human Immunodeficiency Virus infected patients
}

Jigar D. Kapadia, Chetna K. Desai', Ram K. Dikshit', Manish N. Solanki', Asha N. Shah ${ }^{2}$

Departments of Pharmacology, GCS Medical College, Hospital and

Research Center, ${ }^{1}$ B. J. Medical College, ${ }^{2}$ Department of Medicine,

Civil Hospital, Ahmedabad, Gujarat, India

Address for the Correspondence: Dr. Chetna K. Desai, Department of Pharmacology, B. J. Medical College, Asarwa, Ahmedabad - 380016 , Gujarat, India.

E-mail: chetna99@gmail.com

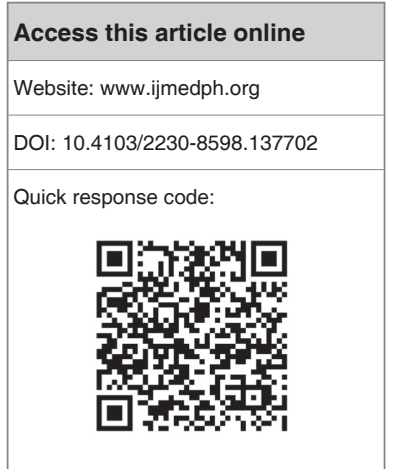

Objectives: The aim was to evaluate the utilization pattern, efficacy and safety of drugs prescribed for opportunistic infections (Ols) in human immunodeficiency virus (HIV) positive patients. Materials and Methods: In this observational, prospective, single center study, HIV positive patients were followed-up for a period of 1 year to record the Ols; their clinical course and outcome. Utilization pattern, efficacy and safety of the drugs used were evaluated. Rationality of treatment was assessed using National AIDS Control Organization and Standard Treatment Guidelines. Results: A total of 222 Ols were detected in 134 patients. Majority of patients (90.2\%) were adults. The commonest Ols included tuberculosis (TB) (89), oropharyngeal candidiasis (OPC) (37), bacterial infections (30) and chronic diarrhea (22). Use of supportive drugs and empirical treatment of certain Ols contributed to a higher number of drugs (average of 3.5 drugs) per prescription. Drugs, prescribed in accordance with the above mentioned guidelines, were effective in most cases. Drugs were well-tolerated with only two serious adverse drug reactions (ADRs) reported. Majority of ADRs were associated with anti TB drugs. Conclusion: Tuberculosis, oropharyngeal candidiasis, bacterial infections and chronic diarrhea are the commonest Ols. Overall, a rational approach to therapy and good tolerability and efficacy of drugs was observed. Empirical treatment of infections should be minimized.

Key words: Adverse drug reactions, efficacy, human immunodeficiency virus, OI, utilization pattern

\section{INTRODUCTION}

Acquired immunodeficiency syndrome (AIDS) is defined as the occurrence of life-threatening opportunistic infections (OIs), malignancies, neurological diseases and other specific illnesses in patients with human immunodeficiency virus (HIV) infection and CD4 counts $<200$ cells $/ \mathrm{mm}^{3} .^{[1]}$ Nearly, 2.27 million people in India are infected with HIV and the prevalence rate in adults is $0.31 \%$ in India. ${ }^{[2]}$ OIs are a chief cause of AIDS related mortality ${ }^{[3]}$ and timely intervention helps to increase longevity and to prevent transmission of these infections in the community. ${ }^{[2]}$

The National AIDS Control Organization (NACO), India classifies OIs into 12 categories and has provided guidelines for their prevention and treatment. These include tuberculosis (TB), oral candidiasis, chronic diarrhea, herpes zoster (HZ), other herpes virus infections, bacterial infections, cytomegalovirus (CMV) retinitis, Pneumocystis jiroveci pneumonia, cryptococcal meningitis, toxoplasmosis, mycobacterium avium complex infection and other OIs. The guidelines recommend the use of specific antimicrobials [Appendices 1 and 2] and other drugs (e.g. glucocorticoids, analgesics, antidiarrheal drugs etc.). ${ }^{[1]}$ However, data regarding utilization, efficacy and safety of these drugs is sparse. This study aimed to evaluate the utilization pattern, efficacy and safety of drugs used in OIs in HIV positive patients.

\section{MATERIALS AND METHODS}

This was an observational, prospective, single center study carried out at the Antiretroviral Therapy (ART) Center of a tertiary care hospital, for a duration of 21 months from September 2010 to June 2012. Approval for conduct of the study was obtained from the Nodal officer, ART Centre; Gujarat 


\begin{tabular}{|c|c|c|c|}
\hline $\begin{array}{l}\text { Opportunistic } \\
\text { infection }\end{array}$ & Recommended drug(s) of choice & Dose and duration of treatment & $\begin{array}{l}\text { Recommended } \\
\text { alternative drugs }\end{array}$ \\
\hline Tuberculosis & $\begin{array}{l}\text { Standard DOTS regimens as per the RNTCP } \\
\text { guidelines }\end{array}$ & According to the RNTCP guidelines** & None \\
\hline $\begin{array}{l}\text { Oro- } \\
\text { pharyngeal } \\
\text { candidiasis }\end{array}$ & $\begin{array}{l}\text { Clotrimazole troche } \\
\text { Nystatin oral suspension } \\
\text { Fluconazole }\end{array}$ & $\begin{array}{l}10 \mathrm{mg} 5 \text { times/day for } 7-14 \text { days } \\
500,000 \text { units gargled } 4-5 \text { times/day } \\
100-200 \mathrm{mg} / \text { day ( } 150 \mathrm{mg} \text { tab, } 1-2 \text { times/day) } \\
\text { for } 7-14 \text { days }\end{array}$ & None \\
\hline $\begin{array}{l}\text { Bacterial } \\
\text { pneumonia }\end{array}$ & $\begin{array}{l}\text { Cefotaxime or ceftriaxone } \\
\text { Levofloxacin } \\
\text { Combination therapy with macrolide or quinolone } \\
\text { with cephalosporin for patients with severe illness. } \\
\text { In patients with CD }<100 \text { cells } / \mathrm{mm}^{3} \text {, previous } \\
\text { pseudomonas infection, bronchiectasis or } \\
\text { neutropenia, empirical coverage should include } \\
\text { agents like ceftazidime, cefepime, piperacillin/ } \\
\text { tazobactam, carbapenems, or high-dose } \\
\text { ciprofloxacin or levofloxacin. If ceftazidime and } \\
\text { ciprofloxacin are used, other antimicrobial agents } \\
\text { may be needed for optimal Gram-positive coverage }\end{array}$ & $\begin{array}{l}\text { Usual recommended therapeutic doses for } \\
\text { non HIV patients for 7-10 days }\end{array}$ & None \\
\hline Herpes zoster & Oral acyclovir & $\begin{array}{l}20 \mathrm{mg} / \mathrm{kg} / \text { day (maximum dose: } 800 \mathrm{mg} 4 \text { or } \\
5 \text { times daily) }\end{array}$ & Famcyclovir \\
\hline HSV infection & Acyclovir & $\begin{array}{l}200 \mathrm{mg} 5 \text { times a day for } 7-10 \text { days (14 days } \\
\text { in cases of recurrence) } \\
5 \mathrm{mg} / \mathrm{kg} \text { IV q } 8 \mathrm{~h} \text { for } 10 \text { days for severe cases } \\
\text { (including encephalitis) }\end{array}$ & None \\
\hline CMV retinitis & Ganciclovir & $\begin{array}{l}\text { Induction therapy: IV ganciclovir } 5 \mathrm{mg} / \mathrm{kg} \text { BD for } \\
2-3 \text { weeks followed by IV OD } 5-7 \text { days a week } \\
\text { Maintenance therapy: Oral treatment } 1000 \\
\text { mg capsules TDS } \\
\text { Maintenance therapy to be continued till the } \\
\text { CD4 count increases to } 200 \text { cells } / \mathrm{mm}^{3} \text { for at } \\
\text { least } 6 \text { months following HAART }\end{array}$ & $\begin{array}{l}\text { IV foscarnet } \\
\text { IV cidofovir } \\
\text { Oral valganciclovir }\end{array}$ \\
\hline $\begin{array}{l}\text { CMV } \\
\text { oesophagitis }\end{array}$ & Ganciclovir and/or foscarnet & $\begin{array}{l}\text { Foscarnet } 60 \mathrm{mg} / \mathrm{kg} \text { IV every } 8 \text { hourly or } 90 \\
\mathrm{mg} / \mathrm{kg} \text { every } 12 \text { hourly (or) } \\
\text { Ganciclovir } 5 \mathrm{mg} / \mathrm{kg} \text { IV BD for } 14-21 \text { days }\end{array}$ & Valganciclovir \\
\hline $\begin{array}{l}P . \text { jirovecii } \\
\text { pneumonia }\end{array}$ & Cotrimoxazole & $\begin{array}{l}\text { Double strength ( } 160 / 800 \mathrm{mg}), 2 \text { tablets TDS } \\
\text { for } 21 \text { days usually }\end{array}$ & $\begin{array}{l}\text { Trimethoprim + dapsone } \\
\text { Clindamycin + primaquine }\end{array}$ \\
\hline $\begin{array}{l}\text { Cryptococcal } \\
\text { meningitis }\end{array}$ & AMB with or without flucytosine & $\begin{array}{l}\text { AMB: } 0.7 \mathrm{mg} / \mathrm{kg} / \mathrm{day} \text {, flucytosine } 25 \mathrm{mg} / \mathrm{kg} \\
\text { QID for } 14 \text { days }\end{array}$ & $\begin{array}{l}\text { AMB + fluconazole }+ \\
\text { flucytosine }\end{array}$ \\
\hline Toxo-plasmosis & Pyrimethamine, sulfadiazine and leucovorin & $\begin{array}{l}\text { Pyrimethamine } 100-200 \mathrm{mg} / \mathrm{day} \text {, } \\
\text { sulfadiazine } 4-8 \mathrm{~g} / \text { day } \\
\text { Initially high doses are given for } 4-8 \text { weeks } \\
\text { followed by maintenance therapy till the CD } 4 \\
\text { count increases to } 200 \text { cells } / \mathrm{mm}^{3} \text { for at least } \\
6 \text { months following HAART }\end{array}$ & $\begin{array}{l}\text { Atovaquone + sulfadiazine } \\
\text { Atovaquone + } \\
\text { pyrimethamine + leucovorin } \\
\text { Azithromycin + } \\
\text { pyrimethamine + leucovorin } \\
\text { Varying combinations } \\
\text { of dapsone, 5-FU, } \\
\text { clarithromycin and } \\
\text { minocycline }\end{array}$ \\
\hline
\end{tabular}

*India. Ministry of Health and Family Welfare. National AIDS control organization. Guidelines for Prevention and Management of Common Opportunistic Infections/ Malignancies among HIV-Infected Adult and Adolescent. May 2007. **Tripathi KD. Antitubercular drugs. In: Tripathi KD, editor. Essentials of Medical Pharmacology. $7^{\text {th }}$ edition. New Delhi: Jaypee Brothers Medical Publishers (P) Ltd., 2013; p. 765-79. NACO = National AIDS Control Organization, DOTS $=$ Directly observed treatment, short-course, HSV = Herpes simplex virus, RNTCP = Revised national tuberculosis control programme, $C M V=$ Cyto-megalovirus, $A M B=A m p h o t e r i c i n ~ B, H A A R T=H i g h l y$ active antiretroviral therapy, P. jirovecii = Pneumocystis jirovecii, $5-\mathrm{FU}=5$-fluorouracil

State AIDS Control Society and the Institutional Ethics Committee (EC) (Ref No. EC/A/93/10/25.10.10).

The investigator attended the outpatient department of ART Center daily. Patients newly diagnosed to be suffering from OI, who were willing to provide a voluntary written informed consent and report for regular follow-up were included. A purposive sampling of the study population was carried out based on the available data of prevalence of different OIs in these patients. Patients were enrolled during the first 9 months of study period and monitored for 1 year for new or recurrent OI. Demographic characteristics (age and gender), mode of HIV transmission, total number and types of OIs, their clinical course and outcome were noted in a pretested case record form. Details of drugs prescribed for treatment of OIs and the associated adverse drug reactions (ADRs) were recorded. Outcome of treatment was assessed by the treating physician and recorded by the investigator. ADRs were evaluated for severity using the modified Hartwig and 
Siegel scale. ${ }^{[4]}$ The Central Drugs Standard Control Organization's criteria $^{[5]}$ for monitoring the progression of ADRs and WHO UMC causality scale and Naranjo's score for causality assessment of ADRs were used. Rationality of treatment was assessed based on the adherence to the $\mathrm{NACO}^{[1]}$ and other recommended guidelines. ${ }^{[6]}$

\section{RESULTS}

\section{Demographic and other characteristics}

A total of 134 patients were enrolled. A follow-up of 1 year was completed in 97 patients $(72.3 \%$ ) (a total follow-up of 97 patient years). The remaining 37 patients $(27.6 \%)$ were either lost to followup or transferred from the study center to other ART centers. Follow-up data of 11.84 patient years was available from these patients. Therefore, a total data of 108.84 patient years was analyzed.

Enrolled patients included 121 adults ( 88 men and 33 women) and 13 children (eight males and five females). Mode of HIV transmission among adults were predominantly heterosexual (61.98\%) and

\begin{tabular}{|c|c|}
\hline \multicolumn{2}{|c|}{$\begin{array}{l}\text { Appendix 2: NACO guidelines for antimicrobial } \\
\text { therapy of chronic diarrhea in HIV Positive } \\
\text { patients* (2007) }\end{array}$} \\
\hline Causative organism & Recommended antimicrobial drug \\
\hline Salmonella & $\begin{array}{l}\text { Ciprofloxacin } 500 \mathrm{mg} \text { BD or Ofloxacin } 400 \\
\mathrm{mg} \text { BD or Ceftriaxone } 2 \mathrm{~g} \text { IV for } 7-10 \text { days } \\
\text { (i.v. treatment is required in presence of } \\
\text { sepsis) } \\
\text { Chronic maintenance therapy (cotrimoxazole } \\
1 \text { double- strength tablet daily) is sometimes } \\
\text { necessary for patients who have relapse }\end{array}$ \\
\hline Shigella & $\begin{array}{l}\text { Cotrimoxazole ( } 160 / 800 \mathrm{mg} \text { BD) or } \\
\text { Amoxicillin } 500 \mathrm{mg} \text { TDS for } 5 \text { days } \\
\text { Resistant cases: Ciprofloxacin } 500 \mathrm{mg} \text { BD } \\
\text { or Norfloxacin } 400 \mathrm{mg} \text { BD for } 5 \text { days or } \\
\text { Nalidixic acid } 1 \mathrm{~g} \text { QID for } 10 \text { days }\end{array}$ \\
\hline Cryptosporidium & $\begin{array}{l}\text { Paramomycin } 500 \mathrm{mg} \text { QID for } 2-3 \text { weeks } \\
\text { Maintenance therapy: } 500 \mathrm{mg} \text { BD (often } \\
\text { required) }\end{array}$ \\
\hline Entamoeba histolytica & Metronidazole $400 \mathrm{mg}$ TDS for 7 days \\
\hline Giardia lamblia & Metronidazole $200 \mathrm{mg}$ p.o. TDS for 10 days \\
\hline Isospora belli & $\begin{array}{l}\text { Cotrimoxazole ( } 160 / 800 \mathrm{mg} \text { QID for } 10 \\
\text { days followed } 160 / 800 \mathrm{mg} \text { BD for } 3 \text { weeks), } \\
\text { followed by chronic suppression with } \\
\text { Cotrimoxazole ( } 160 / 800 \mathrm{mg} \text { ) daily } \\
\text { Alternate: High dose of Pyrimethamine } \\
\text { with Calcium folinate (to prevent } \\
\text { myelosuppression) } \\
\text { Long-term maintenance therapy may be } \\
\text { necessary to prevent relapse }\end{array}$ \\
\hline Microsporidium & $\begin{array}{l}\text { Disseminated disease: Itraconazole } 400 \mathrm{mg} \\
\text { p.o. OD and Albendazole } 400 \mathrm{mg} \text { p.o. BD }\end{array}$ \\
\hline $\begin{array}{l}\text { Strongyloides } \\
\text { stercoralis }\end{array}$ & $\begin{array}{l}\text { Ivermectin } 12 \mathrm{mg} \text { daily for } 3 \text { days or } \\
\text { Albendazole } 400 \mathrm{mg} \text { BD for } 5 \text { days } \\
\text { Maintenance therapy: (to supress } \\
\text { symptomatic infection) } \\
\text { Albendazole } 400 \mathrm{mg} \text { or Ivermectin } 6 \mathrm{mg} \\
\text { once a month }\end{array}$ \\
\hline
\end{tabular}

** India. Ministry of Health \& Family Welfare. National AIDS control organization. Guidelines for Prevention and Management of Common Opportunistic Infections/ Malignancies among HIV-Infected Adult and Adolescent. May 2007.

NACO = National AIDS Control Organization, IV = intravenous through blood transfusion $(15.7 \%)$, while that among children was predominantly vertical $(69.2 \%)$ [Figure 1]. Mean age of adult and pediatric patients were $39.6 \pm 11.59$ years and $9.3 \pm 3.22$ years respectively [Figure 2]. Mean baseline CD4 count of adults and pediatric patients were $178.84 \pm 147.26$ cells $/ \mu \mathrm{l}$ and $642.3 \pm 585.55$ cells $/ \mu$ l respectively $(P<0.0001)$.

\section{Utilization pattern of drugs}

A total of 763 drugs were prescribed in 217 cases (an average of 3.5 drugs/case). Of these, 688 (90.1\%) were prescribed orally, $65(8.5 \%)$ parenterally and $10(1.3 \%)$ by topical route. A total of $580(76 \%)$ antimicrobials were prescribed. Prescribing by generic and brand names was $566(74.1 \%)$ and 197 (25.8\%) respectively. A total of 705 $(92.3 \%)$ drugs were prescribed from hospital pharmacy, whereas 58 $(7.6 \%)$ were prescribed from the private pharmacies. Of 763 drugs, 678 (88.8\%) were included in WHO Essential Medicine List 2011. Treatment details of five cases, where patients received treatment from private practitioners, were not available.

\section{Opportunistic infections}

A total of 222 OIs were observed including TB, oropharyngeal candidiasis (OPC), bacterial infections, chronic diarrhea, acute diarrhea, herpes zoster (HZ), CMV infections, herpes simplex, $P$. jiroveci pneumonia, cryptococcal meningitis and toxoplasmosis. More than one OI was suspected in four cases [Figure 3]. Outcome of OI was not assessable in 29 cases, since the patients were either

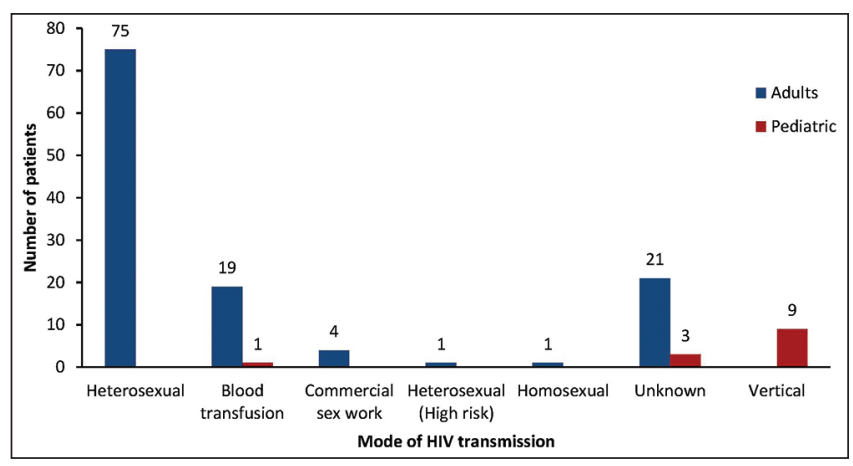

Figure 1: Mode of transmission in HIV positive patients $(n=134)$ with opportunistic infections at a tertiary care hospital, India

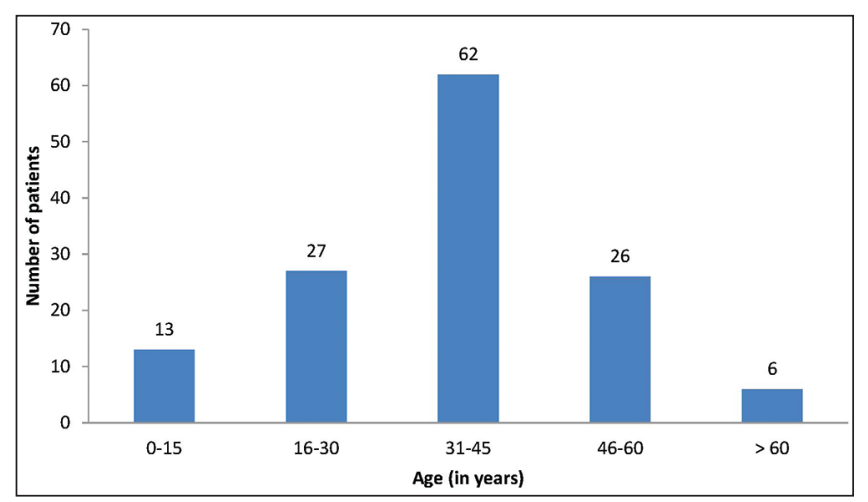

Figure 2: Age distribution of HIV positive patients $(n=134)$ with opportunistic infections at a tertiary care hospital, India 
lost to follow-up or since treatment was continuing at the end of study period.

\section{Tuberculosis}

The results of efficacy and safety of anti TB drugs in HIV positive patients have been published by the authors. ${ }^{[7]}$ Tuberculosis was observed in 89 patients. Abdominal TB, pulmonary TB, combined form of pulmonary and extra pulmonary TB, tuberculous pleural effusion, TB lymphadenitis (cervical) and TB meningitis were observed. All patients were treated in accordance with the Revised National Tuberculosis Control Programme guidelines as recommended by the NACO. Majority $(82.8 \%)$ of the patients were cured, while 12 patients (17.1\%) died.

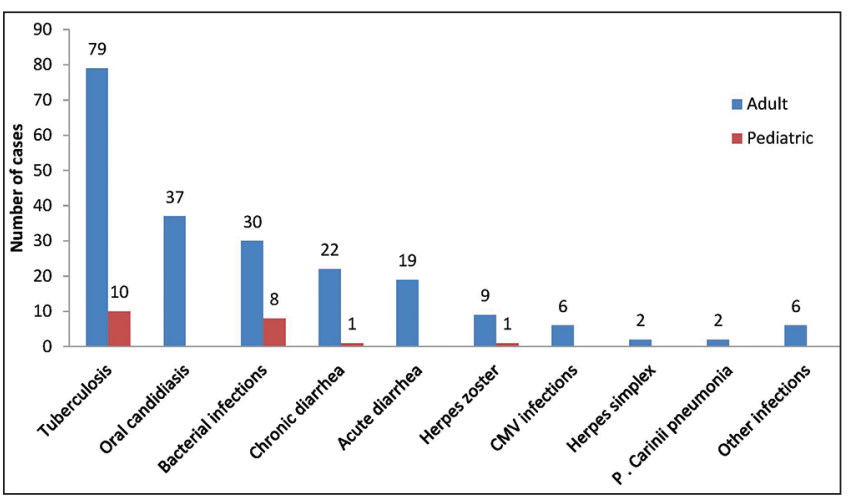

Figure 3: Opportunistic infections $(n=222)$ observed in HIV positive patients $(n=134)$ at a tertiary care hospital, India

\section{Oropharyngeal candidiasis}

A total of 37 cases (26 in men and 11 in women) of OPC were observed in adults with a mean baseline CD4 count of $98.08 \pm$ 80.79 cells $/ \mu$ l. Of these, 24 were observed in ART naive patients. All patients received oral fluconazole therapy as recommended by NACO. In addition, intravenous fluconazole was prescribed in one case and topical clotrimazole in two cases. Outcome was assessable in 32 cases, all of whom were cured. A single episode of recurrence was observed in seven patients. In three adults, both OPC and herpes simplex infection were suspected. It was cured with a combination of acyclovir and fluconazole.

\section{Bacterial infections}

Upper respiratory tract infections (URTI) (18), lower respiratory tract infections (LRTI) (7), skin infections (2), urinary tract infections (UTI) (2) and pyogenic meningitis (1) were observed. Twenty two cases were observed in adults (mean CD 4 count of $269.95 \pm 206.71$ cells $/ \mu \mathrm{l}$ ) and eight in children (mean CD4 count of $816.0 \pm 682$. 36 cells $/ \mu \mathrm{l})$. Twenty five cases were observed in patients receiving ART. Amoxicillin and co-amoxiclav were the most frequently prescribed antimicrobial agents. All except two cases of LRTI were cured [Table 1].

Bacterial skin infections (boils and otitis externa) were cured with recommended doses of oral antibacterial drugs (co-amoxiclav and amoxicillin respectively), topical antibacterial drugs (polymyxin B

\begin{tabular}{|c|c|c|c|c|}
\hline \multirow[t]{2}{*}{ Drug } & \multicolumn{4}{|c|}{ Upper respiratory tract infections $(n=18)$} \\
\hline & Formulation & Dosage & $\begin{array}{c}\text { Duration of } \\
\text { treatment (days) }\end{array}$ & $\begin{array}{l}\text { Number } \\
\text { of cases }\end{array}$ \\
\hline \multirow[t]{3}{*}{ Amoxicillin } & Capsule or tablet $(500 \mathrm{mg})$ & TDS & $5-7$ & 9 \\
\hline & Tablet $(125 \mathrm{mg})^{*}$ & TDS & $5-7$ & 4 \\
\hline & Capsule $(250 \mathrm{mg})^{*}$ & TDS & 5 & 1 \\
\hline Erythromycin & Tablet $(250 \mathrm{mg})^{*}$ & TDS & 7 & 1 \\
\hline \multirow[t]{2}{*}{ Co-amoxiclav } & Tablet (625 mg) & TDS & 5 & 1 \\
\hline & & Half tablet TDS* & 7 & 1 \\
\hline Paracetamol & Tablet (500 mg) & sos & 7 & 2 (1 child) \\
\hline \multirow[t]{2}{*}{ Cetirizine } & Tablet (10 mg) & OD & 5 & 2 (1 child) \\
\hline & & $\mathrm{BD}$ & $5-7$ & 5 \\
\hline Pheniramine maleate & Tablet $(25 \mathrm{mg})^{*}$ & Half tablet OD & 5 & 1 \\
\hline $\begin{array}{l}\text { Chlorpheniramine maleate }+ \\
\text { d-methorphan hydrobromide }+ \\
\text { guaifenesin }+ \text { phenylephrine } \mathrm{HCl}\end{array}$ & $\begin{array}{l}\text { d-methorphan } 10 \mathrm{mg} \text {, guaifenesin } 100 \mathrm{mg} \text {, } \\
\text { phenylephrine } \mathrm{HCl} 5 \mathrm{mg} \text {, chlorpheniramine } \\
\text { maleate } 4 \mathrm{mg} / 5 \mathrm{ml} \text { syrup* }\end{array}$ & TDS & 7 & 1 \\
\hline \multicolumn{5}{|c|}{ Lower respiratory tract infections $(n=5)$} \\
\hline \multirow[t]{3}{*}{ Co-amoxiclav } & Capsule or tablet $(625 \mathrm{mg})$ & TDS & $7-14$ & 3 \\
\hline & Tablet $(200 \mathrm{mg})^{*}$ & 2.5 tablets in a day & 7 & 1 \\
\hline & $\begin{array}{l}\text { Amoxicillin } 200 \mathrm{mg} \text {, clavulanic acid } 28.5 \mathrm{mg} / 5 \mathrm{ml} \\
\text { syrup* }^{*}\end{array}$ & $5 \mathrm{ml}$ TDS & 5 & 1 \\
\hline Levofloxacin & Tablet $(500 \mathrm{mg})$ & OD & 5 & 1 \\
\hline Ciprofloxacin & Tablet (500 mg) & $\mathrm{BD}$ & 7 & 1 \\
\hline Co trimoxazole & Tablet (960 mg) & 2 tablets OD & 5 & 1 \\
\hline Paracetamol & Tablet $(500 \mathrm{mg})^{*}$ & Half tablet TDS & 5 & 1 \\
\hline $\begin{array}{l}\text { Terbutaline }+ \text { ambroxol }+ \\
\text { guaiphenesin }+ \text { menthol syrup }\end{array}$ & $\begin{array}{l}\text { Terbutaline } 1.25 \mathrm{mg} \text {, ambroxol } 15 \mathrm{mg} \text {, } \\
\text { guaiphenesin } 5 \mathrm{mg} \text {, menthol } 2.5 \mathrm{mg} / 5 \mathrm{ml}^{*}\end{array}$ & TDS-QID & 7 & 1 \\
\hline
\end{tabular}

Details of two patients suffering from pneumonia were not available. *Formulations prescribed to pediatric patients 
sulfate + neomycin sulfate + gramicidin ear drops, beclomethasone dipropionate + neomycin + clotrimazole cream and nadifloxacin cream), analgesics (ibuprofen) and pheniramine maleate. Urinary tract infections were cured with oral fluoroquinolones in usual doses. Pyogenic meningitis was cured with ceftriaxone, metronidazole, phenytoin, ondansetron, paracetamol and dextrose normal saline followed by cefixime. Chloroquine was also prescribed initially as empirical treatment for suspected malaria.

\section{Chronic diarrhea}

Of the 22 cases of chronic diarrhea, 21 were observed in adults (mean CD 4 count of $208.14 \pm 179.94$ cells $/ \mu \mathrm{l}$ ). Of these, 16 were ART naïve. A total of 90 drugs were prescribed (an average of 4.09 drugs/case) [Table 2]. Patients were treated empirically with more than one antimicrobial agent in $17(77.2 \%)$ cases without prior stool examination. Mean duration of antimicrobial treatment was 10.23 \pm 6.60 days. All the drugs were used in the usual recommended doses. Of the 21 cases with assessable outcomes, 17 were cured, three did not improve and one died, while recurrence was observed in one case.

\section{Acute diarrhea}

Nineteen cases of acute diarrhea were observed in adults (15 in men and four in women; mean CD4 count of $284.05 \pm 271.72$ cells $/ \mu l)$. Abdominal TB was observed in five patients, while four patients had suffered from chronic diarrhea earlier. Both abdominal TB and a history of chronic diarrhea were present in two patients. A total of 48 drugs were prescribed in 18 cases (an average of 2.66 drugs per case) [Table 3].

\begin{tabular}{|c|c|c|c|c|}
\hline Drug & Formulation & Dosage & $\begin{array}{l}\text { Duration of } \\
\text { treatment } \\
\text { (days) }\end{array}$ & $n$ \\
\hline \multirow{2}{*}{ Metronidazole } & Tablet $(400 \mathrm{mg})$ & TDS & $5-7$ & 4 \\
\hline & Pint (500 mg/100 ml) & TDS & $5-7$ & 4 \\
\hline \multirow[t]{4}{*}{ Ciprofloxacin } & Tablet (500 mg) & $\mathrm{BD}$ & $5-7$ & 3 \\
\hline & Pint $(200 \mathrm{mg} / 100 \mathrm{ml})$ & 1 pint $B D$ & 1 & 1 \\
\hline & & & 2 & 1 \\
\hline & & & 5 & 2 \\
\hline Ofloxacin & Pint (200 mg/100 ml) & 1 pint BD & 4 & 1 \\
\hline \multirow[t]{7}{*}{ Nitazoxanide } & Tablet (500 mg) & OD & 7 & 1 \\
\hline & & $\mathrm{BD}$ & $7-10$ & 8 \\
\hline & & & 35 & 1 \\
\hline & & TDS & $5-10$ & 7 \\
\hline & Tablet $(200 \mathrm{mg})^{\star}$ & TDS & 15 & 1 \\
\hline & Tablet $(1 \mathrm{~g})$ & $\mathrm{BD}$ & 5 & 1 \\
\hline & Capsule (500 mg) & $\mathrm{BD}$ & 5 & 1 \\
\hline \multirow[t]{5}{*}{ Co-trimoxazole } & Tablet (480 mg) & 2 tablets OD & 10 & 1 \\
\hline & & 2 tablets BD & $5-15$ & 5 \\
\hline & & & 1 & 1 \\
\hline & Tablet (960 mg) & OD & 7 & 1 \\
\hline & & $\mathrm{BD}$ & $7-10$ & 2 \\
\hline \multirow[t]{2}{*}{ Doxycycline } & Capsule (100 mg) & 3 capsules stat & Stat & 4 \\
\hline & & $\mathrm{BD}$ & 15 & 1 \\
\hline \multirow[t]{2}{*}{ Albendazole } & Tablet (400 mg) & 1 tablet HS & $7-15$ & 3 \\
\hline & & 1 tablet stat & Stat & 1 \\
\hline Levofloxacin & Tablet (750 mg) & OD & 15 & 1 \\
\hline
\end{tabular}

\begin{tabular}{|c|c|c|c|c|}
\hline Drug & Formulation & Dosage & $\begin{array}{c}\text { Duration of } \\
\text { treatment (days) }\end{array}$ & $n$ \\
\hline \multirow[t]{2}{*}{ Metronidazole } & Tablet (400 mg) & TDS & $5-7$ & 4 \\
\hline & Pint $(500$ mg/100 ml) & TDS & $5-7$ & 2 \\
\hline \multirow[t]{3}{*}{ Ciprofloxacin } & Tablet $(500 \mathrm{mg})$ & BD & $5-7$ & 5 \\
\hline & Pint (200 mg/100 ml) & BD & 5 & 1 \\
\hline & & & 1 & 1 \\
\hline \multirow[t]{2}{*}{ Norfloxacin } & Tablet (400 mg) & BD & 5 & 2 \\
\hline & Pint & BD & 1 & 1 \\
\hline Ofloxacin & Pint $(200$ mg/100 ml) & $\mathrm{BD}$ & 1 & 1 \\
\hline \multirow[t]{2}{*}{ Nitazoxanide } & Tablet $(500 \mathrm{mg})$ & TDS & $5-7$ & 3 \\
\hline & & $\mathrm{BD}$ & $5-7$ & 7 \\
\hline Cotrimoxazole & Tablet (480 mg) & Two tablets OD & 15 & 1 \\
\hline Doxycycline & Capsule (100 mg) & $\mathrm{BD}$ & 15 & 1 \\
\hline Albendazole & Tablet $(400 \mathrm{mg})$ & 1 tablet HS & 7 & 1 \\
\hline $\begin{array}{l}\text { Ofloxacin + ornidazole } \\
\text { combination }\end{array}$ & $\begin{array}{l}\text { Ofloxacin }(200 \mathrm{mg})+\text { ornidazole }(500 \mathrm{mg}) \\
\text { combination tablet }\end{array}$ & $\mathrm{BD}$ & 5 & 1 \\
\hline ORS & Powder & sos & $5-15$ & 9 \\
\hline \multirow{3}{*}{$\begin{array}{l}\text { Lactobacillus } \\
\text { sporogenes }\end{array}$} & 60 million/tablet & 2 tablets TDS & $5-7$ & 4 \\
\hline & & 2 tablets QID & 5 & 1 \\
\hline & 120 million/tablet & 1 tablet TDS & 7 & 1 \\
\hline Normal saline & Pint $(500 \mathrm{ml})$ & $\mathrm{BD}$ & 5 & 1 \\
\hline Hyoscine butyl bromide & Tablet $(10 \mathrm{mg})$ & $\mathrm{BD}$ & 7 & 1 \\
\hline
\end{tabular}

$n=$ Number of cases receiving the treatment (treatment details of one patient was not available). ORS = Oral rehydration salt 
Treatment details of one patient were not available. Mean duration of antimicrobial use in these patients was $7.72 \pm 3.32$ days. Switching between different fluoroquinolones, that is, ciprofloxacin, norfloxacin and ofloxacin was observed in one patient. All except one were cured.

\section{Herpes zoster}

Nine cases of HZ (eight adults and one child) were observed. Mean baseline CD 4 count of adults was $220.71 \pm 102.56$ cells $/ \mu 1$. Herpes zoster occurred within 3 and 6 months of initiation of ART in three cases each and within 12 months of initiation of ART in one. Patients were prescribed acyclovir in accordance with the NACO guidelines. ${ }^{[1]}$ Other drugs, that is, nonsteroidal antiinflammatory drugs (NSAIDs), antihistaminics, calamine lotion and gabapentin-mecobalamin combination were used in usual recommended doses. Two patients were also prescribed topical and/or systemic antibacterial drugs (framycetin, neomycin and ciprofloxacin). Treatment details of one patient were not available. Six patients, in whom outcome was assessable, were cured.

\section{Herpes simplex}

Herpes simplex labialis was observed in two adults (mean CD4 count of $111.5 \pm 75.66$ cells $/ \mu \mathrm{l}$ ), one of whom was ART naive. Patients received oral acyclovir in the usual recommended doses and were cured.

\section{Cytomegalovirus retinitis}

Cytomegalovirus retinitis was observed in five adults (mean baseline CD4 count of $138.8 \pm 165.44$ cells $/ \mu \mathrm{l})$ CD 4 count was $<50$ cells/ $\mu \mathrm{l}$ in three cases. One patient, suffering from Burkitt's lymphoma, had a baseline CD4 count of 341 cells/ $\mu$ l. Four patients received oral valganciclovir in accordance with the NACO guidelines. ${ }^{[1]}$ Progressive visual loss was arrested in these cases. Outcome was not assessable in one patient.

\section{Cytomegalovirus esophagitis}

Cytomegalovirus esophagitis was observed in a 16-year-old ART naive male with a baseline CD4 count of 112 cells/ $\mu$ l. Patient was cured with oral valganciclovir prescribed in usual recommended doses.

\section{Other opportunistic infections}

Pneumocystis jiroveci pneumonia was observed in two ART naive adult males. Patients were treated with combination antimicrobial therapy, corticosteroids, furosemide, paracetamol and expectorants in the usual doses. Cotrimoxazole was used in the doses of 3.84 and $5.76 \mathrm{~g} /$ day in one case each for a mean duration of $11.0 \pm 5.66$ days. One of the patients died during treatment. Cryptococcal meningitis, observed in a patient who was also receiving category II anti TB drugs for TB meningitis, was cured with intravenous amphotericin B, fluconazole and supportive drugs used for 15 days as recommended. Toxoplasmosis was observed in one patient, who was also suffering from sputum positive pulmonary TB and had a recent history of chronic diarrhea. Pyrimethamine, clindamycin, cefotaxime, cefoperazone-sulbactam, fluconazole and aspirin were prescribed in the usual recommended doses, but the patient succumbed to the infection.

\section{Antiretroviral therapy and changes in antiretroviral therapy due to opportunistic infections}

Of 134 patients, 103 were ART naive at enrollment. ART was initiated as per the NACO guidelines in majority of naive patients. Boosted protease inhibitor (PI) (lopinavir/ritonavir) were prescribed to one patient developing failure of first line ART. Nevirapine was substituted with efavirenz in ten patients with TB due to a potential of interaction between nevirapine and rifampicin. Efavirenz was substituted with nevirapine after completion of anti TB treatment in 47 patients.

\section{Adverse drug reactions}

A total 165 ADRs were observed [Table 4]. Most ADRs $(n=149$, $90.3 \%$ ) were associated with anti TB drugs. Majority of ADRs were mild in nature $(n=163,98.7 \%)$ with a severity of level 1 as per the modified Hartwig and Siegel scale. Gastrointestinal ADRs $(n=64)$ were most frequent. Two serious ADRs (severity level 2 and 3 in one case each) observed included generalized skin rash progressing

Table 4: Adverse drug reactions $(n=165)$ due to
drugs prescribed for opportunistic infections in
HIV positive patients $(n=134)$

\begin{tabular}{lll}
\hline Adverse drug reaction & Suspected medication(s) & $\boldsymbol{n}$ \\
\hline Discoloration of urine & Rifampicin* & 58
\end{tabular}

Gl adverse drug reactions Antituberculosis drugs* 53

(nausea, vomiting, abdominal Fluconazole 3

discomfort, gastritis, diarrhea, Valganciclovir 4

anorexia, reflux oesophagitis Cefotaxime, amikacin, co 1 and constipation) trimoxazole, azithromycin, methyl prednisolone, furosemide, paracetamol, prednisolone Ciprofloxacin, metronidazole, co trimoxazole, nitazoxanide, fluconazole

Co amoxiclav, azithromycin, cotrimoxazole, prednisolone, paracetamol

Cotrimoxazole, nitazoxanide 1

Skin reactions (rashes, pruritus)

Hepatitis (elevation of liver enzymes)

CNS adverse drug reactions (vertigo, headache, sedation and giddiness)

Antituberculosis drugs*

Antituberculosis drugs*

Chlorpheniramine maleate $\quad 1$

Antituberculosis drugs* $\quad 8$

Fluconazole, acyclovir $\quad 1$

Fluconazole 1

Cotrimoxazole, nitazoxanide 1

Miscellaneous adverse drug reactions (gabhraman, weakness, numbness in Antituberculosis drugs*

Chlorpheniramine maleate, ibuprofen

thighs, tingling in legs, fever with chills, fatigue with Valganciclovir, ethambutol* blurring of vision)

$\mathrm{GI}=$ Gastrointestinal, CNS = Central nervous system. $n=$ Number of adverse events.

*Kapadia JD, Desai CK, Solanki MN, Shah AN, Dikshit RK. Efficacy and safety

of antituberculosis drugs in HIV positive patients: A prospective study. Indian J

Pharmacol 2013;45:447-52 
to peeling of skin due to rifampicin and hepatitis (serum glutamic pyruvic transaminase level of $216 \mathrm{IU} / \mathrm{L}$; normal: 0-35 IU/L) due to isoniazid and/or rifampicin. Suspect drugs were withdrawn in both cases following which the ADRs subsided. Causality assessment with the WHO UMC scale showed that the suspect drug had a possible association with the ADR in 101 cases, probable in 63 and certain in one case. As per the Naranjo score, causality scale showed a possible association in 101 and a probable association in 64 cases.

\section{DISCUSSION}

Opportunistic infections are one of the important causes of mortality in AIDS. ${ }^{[2]}$ The National AIDS Control Organization, India has recommended guidelines for prevention and treatment of these infections. ${ }^{[1]}$ However, data regarding efficacy and safety of drugs used to treat OIs is limited. This study was therefore conducted to evaluate the utilization pattern, efficacy and safety of these drugs.

A total of 222 OIs were observed. Most common OI observed was Tuberculosis, followed by oropharyngeal candidiasis, bacterial infections, chronic diarrhea, acute diarrhea and herpes zoster. Less common OIs included herpes simplex, P. jiroveci pneumonia, cryptococcal meningitis and toxoplasmosis. Our findings differ from those of a study carried out in Kolkata, India, in which oral candidiasis, chronic diarrhea and herpes simplex virus (HSV)-2 infections were the commonest OIs followed by TB and CMV infections. ${ }^{[2]}$ Further studies are recommended to determine the reasons for these variations.

Opportunistic infections were more frequent in middle aged males in our study. A study of hospitalized HIV positive patients carried out at Pune, India also showed that male patients with a mean age of 35.2 years were commonly affected. ${ }^{[8]}$ OIs in these young patients affect work output and increase the overall health expenditure. The mean baseline CD4 count of children was significantly higher when compared to adults and OIs were less common in children. This can be attributed to a progressive loss of lymphoid tissue $e^{[9]}$ and deterioration of $\mathrm{T}$-cell function with increasing age.

Antimicrobials were most frequently prescribed drugs. A number of concomitant medications such as pyridoxine, NSAIDs, antihistaminics, glucocorticoids, ORS, intravenous fluids, lactobacillus sporogenes, racecadotril, bronchodilators etc., were also prescribed. Nearly $66 \%$ patients were prescribed antitubercular drugs. This increased the number of drugs per prescription. While this treatment was rational and as per the NACO guidelines, the number of drugs per prescription was also high in cases of acute and chronic diarrhea due to empirical treatment. A routine stool examination of HIV positive patients suffering from diarrhea is therefore recommended to optimize drug therapy. Empirical treatment was also employed in pyogenic meningitis, pneumocystis jirovcei pneumonia and toxoplasmosis, which could have been avoided.

Majority drugs were prescribed orally and by their generic names, except certain antimicrobials. Parenteral therapy was required only in serious infections such as PCP, meningitis and severe diarrhea.
Overall, a rational approach in the selection of drugs and their formulations was observed. Most drugs were dispensed free of cost from the hospital pharmacy, which is important to ensure adherence to treatment in these patients and reduces the treatment burden of the patients. The choice of drugs was in concurrence with the NACO guidelines and WHO Essential Medicine List 2011.

Tuberculosis was the most common OI observed with extra pulmonary and abdominal TB being more frequent. All patients were treated as recommended by NACO and majority were cured. Tuberculosis was the most common cause of death in our study as has been suggested by other researchers too. ${ }^{[10]}$ The three I's for HIV-TB as recommended by WHO, that is, intensified TB case finding, isoniazid preventive therapy and infection control for $\mathrm{TB},{ }^{[11]}$ is recommended in these patients.

Oropharyngeal candidiasis was the second most common OI observed. Oral thrush commonly occurs and recurs in patients with CD4 cells $<200 / \mu 1,{ }^{[12]}$ which was also observed in this study. Oral fluconazole, prescribed in accordance with the NACO guidelines in all cases, was curative. However, few patients received a combination therapy of oral fluconazole with parenteral fluconazole and/or topical clotrimazole, which unnecessarily exposed patients to more drugs and increased the cost of therapy.

Bacterial infections were the third most common OI observed. URTI was commonest followed by LRTI. Bacterial skin infections, UTI and pyogenic meningitis were less common. Bacterial URTI was treated with the recommended drugs in the usual recommended doses and were cured. Antihistaminics, frequently prescribed to these patients, are primarily indicated in viral rhinitis but not in bacterial URTI. ${ }^{[6]}$ Other drugs were also used in recommended doses. Most LRTIs in the present study were less severe and were managed on outpatient basis. Irrational prescribing has been observed for respiratory tract infections, ${ }^{[13]}$ however, it was less common in our study.

Although genitourinary infections are frequent in HIV positive patients, ${ }^{[14]}$ UTI was not a common infection in the present study. Fluoroquinolones were used to treat these infections in the present study. However, use of fluoroquinolones is restricted for the treatment of complicated UTI and not for the regular treatment of uncomplicated cases. ${ }^{[15]}$ Use of multiple formulations and multiple drugs for bacterial skin infections could have been optimized.

Pyogenic meningitis was treated with multiple antimicrobials. The choice of initial empirical therapy depends on patient's age and health status. ${ }^{[16]}$ In patients with suspected impaired cell mediated immunity, a combination of third generation cephalosporin and ampicillin is recommended as initial empirical therapy. ${ }^{[16]}$ Patient in the present study received initial empirical therapy with ceftriaxone. Furthermore, this patient received chloroquine as a part of initial treatment for suspected cerebral malaria and metronidazole for suspected gram negative anaerobic infection. Inappropriate antimicrobial use increases the risk of drug resistance. The choice of initial empirical therapy needs to be reviewed in such cases. 
Diarrhea was the fourth common OI observed. As chronic diarrhea can be caused by multiple organisms, stool examination helps a definitive diagnosis. ${ }^{[1]}$ Stool examination, however, was not performed in these cases and majority patients received a combination antimicrobial therapy. Diarrhea of parasitic origin is more frequent in AIDS patients in developing countries ${ }^{[17]}$ and accordingly, nitazoxanide was frequently prescribed to these patients. However, the role of nitazoxanide in the management of cryptosporidial diarrhea is not clear. ${ }^{[14]}$ Ciprofloxacin and metronidazole were also commonly co-prescribed in the absence of definitive diagnosis and hence considered irrational. Lactobacillus sporogenes and racedotril, an intestinal enkephalinase inhibitor used in secretory diarrhea were frequently prescribed. However, efficacy of L. sporogenes as a probiotic ${ }^{[18]}$ and that of racecadotril for treatment of watery diarrhea in adults ${ }^{[19]}$ is questionable. Loperamide or codeine phosphate, recommended by NACO as antidiarrheal agents in cases of cryptosporidiosis, ${ }^{[1]}$ were not prescribed to these patients. Many patients of diarrhea were later detected to be suffering from underlying abdominal TB. An ultrasonographic examination is therefore recommended for early detection and treatment of this infection. Majority patients of acute diarrhea were also treated empirically with multiple antimicrobials.

Herpes zoster (HZ) was more common in adults receiving ART. Majority of these patients $(85.7 \%)$ developed HZ within 6 months of initiation of ART, which may be a manifestation of immune reconstitution due to initiation of ART. ${ }^{[1]}$ These patients received oral acyclovir in accordance with NACO guidelines ${ }^{[1]}$ and were cured. Analgesics, antihistaminics and calamine lotion were used to treat associated symptoms as recommended. ${ }^{[6]}$ Use of topical and/or systemic antibacterial agents in a few cases, however, was questionable. Herpes Simplex Virus infection was not frequent in the study population. These patients also received oral acyclovir in accordance with the NACO guidelines ${ }^{[1]}$ and were cured. A few patients presenting with mixed clinical features of both OPC and HSV infection were treated empirically with usual doses of fluconazole and acyclovir and were cured.

The most common manifestation of CMV infection was CMV retinitis, a finding also supported by Jabs. ${ }^{[20]}$ Cytomegalovirus causes end organ disease typically in patients with CD 4 cells $<50 / \mu$ l. In a study investigating the prevalence and management of CMV retinitis in China, the mean baseline CD 4 count of 23 AIDS patients suffering from CMV retinitis was $31.7 \pm 38.6$ cells $/ \mu 1 .{ }^{[21]}$ In this study, however, patients of CMV retinitis had a mean baseline CD4 count of $138.8 \pm 165.44$ cells $/ \mu$ l. Furthermore, of the six patients suffering from CMV infection, only three had a baseline CD4 count $<50$ cells $/ \mu$ l. The small sample size could explain this discrepancy. Nonetheless, further studies are recommended to determine the co relation between CMV infections and the CD4 count in these patients. CMV infections were treated with oral valganciclovir in accordance with the NACO guidelines. ${ }^{[1]}$ CMV esophagitis was cured and the progression of CMV retinitis was arrested. Treatment with oral valganciclovir improves the patient compliance and reduces the risk of intravenous therapy associated with ganciclovir. ${ }^{[22]}$ As visual loss is irreversible in cases of CMV retinitis, ${ }^{[1]}$ early detection of the condition with the help of routine fundus examination in patients with CD4 cells $<50 / \mu$ is recommended. ${ }^{[23]}$

Pneumocystis jiroveci pneumonia was observed in two patients. Incidence of this infection has declined due to availability of antimicrobial prophylaxis and introduction of highly active antiretroviral therapy. ${ }^{[2]}$ Patients were treated with cotrimoxazole and other drugs in accordance with NACO guidelines. ${ }^{[1]}$ One of the patients died during treatment. Since an increasing prevalence of mutant pneumocystis isolates who show resistance to sulfa drugs has been reported, ${ }^{[25]}$ drug sensitivity test of pulmonary isolates may be recommended in these patients.

Cryptococcal meningitis was observed in one patient, who also had concomitant TB meningitis. Patient was cured with amphotericin B and fluconazole prescribed in accordance with the NACO guidelines ${ }^{[1]}$ and other supportive medications in usual recommended doses.

Toxoplasma infection was also rare. Patient was treated with pyrimethamine-clindamycin combination therapy as recommended by NACO ${ }^{[1]}$ Multiple antimicrobials were used initially for empirical treatment. Patient died during treatment, however, this patient was also suffering from pulmonary TB and had a history of chronic diarrhea, which might have contributed to the mortality.

\section{Antiretroviral therapy}

Majority of patients $(76.8 \%)$ suffering from OI were ART naive at the time of enrollment. ART restores the immune response of the patient and protects the patients from the risk of OIs. Accordingly, OIs were less common in patients receiving ART. ART was initiated in majority of naive patients in accordance with the NACO guidelines.

Under the National AIDS Control Program, India, Protease inhibitors are prescribed only to HIV positive patients developing clinical, immunological or virological failure in spite of receiving first line ART drugs for at least 6 months. Protease inhibitors have been documented to exert a protective effect against the risk of toxoplasmic encephalitis ${ }^{[26]}$ and OPC, ${ }^{[27]}$ and beneficial effects in cases of chronic diarrhea. ${ }^{[28,29]}$ Use of PIs is also associated with significant improvement in survival rates of patients suffering from CMV retinitis. ${ }^{[30]}$ However, only one patient in the study group, who developed immunological failure in spite of receiving first line ART drugs, was prescribed PIs. Inclusion of PIs like lopinavir/ritonavir, atazanavir etc. in the first line ART regimes for patients suffering from the above mentioned OIs may be considered.

\section{Changes in antiretroviral therapy due to opportunistic infections}

Nevirapine was substituted with efavirenz in all patients who developed TB, to avoid the risk of interaction between rifampicin and nevirapine as recommended in the guidelines. ${ }^{[1]}$ However, some 
studies have indicated no significant alterations of plasma rifampicin or nevirapine level in patients receiving both drugs. ${ }^{[11,32]}$

\section{Adverse drug reactions}

A total of 165 ADRs were observed. In spite of the fact that these patients were receiving multiple drugs, ADRs were less common indicating that these drugs are well tolerated. Gastrointestinal ADRs were most frequent, which could be attributed to the fact that majority of drugs were prescribed orally. Dermatological ADRs, which are more frequent in HIV positive patients, ${ }^{[18]}$ were not frequent in the present study. Majority of ADRs were nonserious and withdrawal of suspect drug was required only in two cases. Prescription of drugs in accordance with the treatment guidelines might have accounted for their tolerability and safety.

\section{CONCLUSION}

Tuberculosis, oropharyngeal candidiasis, bacterial infections and chronic diarrhea are the most common opportunistic infections observed in HIV positive patients. Majority of OIs are treated with antimicrobial therapy and supportive drugs in accordance with the NACO and Standard Treatment Guidelines. The number of drugs per prescription is high because of use of multiple drugs and empirical treatment of some cases. Prescription from WHO Essential Medicine List 2011 and prescribing by generic name are the good prescribing practices observed. Majority drugs are dispensed from hospital pharmacy, reducing the cost burden. The drugs used for OI are effective and well tolerated in majority patients, with cure and nonrecurrence observed in most cases. Majority of ADRs are nonserious and do not warrant a change in therapy. Definitive diagnosis with appropriate laboratory tests is recommended in cases of bacterial infections and diarrhea. Inclusion of protease inhibitors in first line antiretroviral treatment needs reevaluation in certain OIs considering their protective role in these cases.

\section{LIMITATIONS OF THE STUDY}

The sample size was not adequate to evaluate rarer OIs. However, in spite of these limitations, the findings of the study are valuable vis-avis $\mathrm{OI}$ in HIV positive patients in the Indian context, with particular reference to the implementation and efficacy of recommended treatment guidelines.

\section{ACKNOWLEDGMENT}

We gratefully acknowledge Gujarat State AIDS Control Society (GSACS) for granting us the permission to conduct the study in ART Center, Civil Hospital Ahmedabad.

\section{REFERENCES}

1. India. Ministry of Health \& Family Welfare. National AIDS Control Organization. Guidelines for Prevention and Management of Common Opportunistic Infections/Malignancies among HIV-Infected Adult and Adolescent; May 2007.
2. Saha K, Firdaus R, Santra P, Pal J, Roy A, Bhattacharya MK, et al. Recent pattern of co-infection amongst HIV seropositive individuals in tertiary care hospital, Kolkata. Virol J 2011;8:116.

3. Stickney DR, Noveljic Z, Garsd A, Destiche DA, Frincke JM. Safety and activity of the immune modulator HE2000 on the incidence of tuberculosis and other opportunistic infections in AIDS patients. Antimicrob Agents Chemother 2007; 51:2639-41.

4. Hartwig SC, Siegel J, Schneider PJ. Preventability and severity assessment in reporting adverse drug reactions. Am J Health Syst Pharm 1992;49:2229-32.

5. Suspected Adverse Drug Reaction Reporting Form. Central Drug Standard Control Organization. Available from: http://www.cdsco.nic.in/ ADR_form_PvPI.pdf. [Last accessed on 2013 Jul 21].

6. Delhi Society for Promotion of Rational Use of Drugs. ENT diseases. In: Sharma S, Sethi GR, Gupta U, editors. Standard Treatment Guidelines-A Manual for Medical Theapeutics. $3^{\text {rd }}$ ed. New Delhi: B R Publications Pvt. Ltd.; 2009. p. 235-40.

7. Kapadia JD, Desai CK, Solanki MN, Shah AN, Dikshit RK. Efficacy and safety of anti-tuberculosis drugs in HIV-positive patients: A prospective study. Indian J Pharmacol 2013;45:447-52.

8. Sobhani R, Basavaraj A, Gupta A, Bhave AS, Kadam DB, Sangle SA, et al. Mortality \& clinical characteristics of hospitalized adult patients with HIV in Pune, India. Indian J Med Res 2007;126:116-21.

9. Yan J, Greer JM, Hull R, O'Sullivan JD, Henderson RD, Read SJ, et al. The effect of ageing on human lymphocyte subsets: Comparison of males and females. Immun Ageing 2010;7:4.

10. Getahun H, Kittikraisak W, Heilig CM, Corbett EL, Ayles H, Cain KP, et al. Development of a standardized screening rule for tuberculosis in people living with HIV in resource-constrained settings: Individual participant data meta-analysis of observational studies. PLoS Med 2011;8:e1000391.

11. World Health Organization. Guidelines for Intensified Tuberculosis CaseFinding and Isoniazid Preventive Therapy for People Living with HIV in Resource-Constrained Settings. Switzerland: WHO Library Cataloguingin-Publication Data; 2011. p. 52.

12. Sangeorzan JA, Bradley SF, He X, Zarins LT, Ridenour GL, Tiballi RN, et al. Epidemiology of oral candidiasis in HIV-infected patients: Colonization, infection, treatment, and emergence of fluconazole resistance. Am J Med 1994;97:339-46.

13. Gjelstad S, Fetveit A, Straand J, Dalen I, Rognstad S, Lindbaek M. Can antibiotic prescriptions in respiratory tract infections be improved? A cluster-randomized educational intervention in general practice - The Prescription Peer Academic Detailing (Rx-PAD) Study [NCT00272155]. BMC Health Serv Res 2006;6:75.

14. Fauci $\mathrm{A}$, Lane $\mathrm{H}$. Human immunodeficiency virus disease: AIDS and related disorders. In: Kasper D, Braunwald E, Fauci A, Hauser S, Longo D, Jameson J, editors. Harrison's Principles of Internal Medicine. $16^{\text {th }}$ ed. New York: McGraw-Hill; 2005. p. 1076-120.

15. Satoskar RS, Rege NN, Bhandarkar SD. Sulfonamides, trimethoprim, cotrimoazole, nitrofurans and quinolones. In: Satoskar RS, Rege NN, Bhandarkar SD, Satoskar RR, editors. Pharmacology and Pharmacotherapeutics. $22^{\text {nd }}$ ed. Mumbai: Popular Prakashan Pvt. Ltd.; 2011. p. 635-50.

16. Roos KL, Tyler KL. Meningitis, encephalitis, brain abscess and empyema. In: Kasper D, Braunwald E, Fauci A, Hauser S, Longo D, Jameson J, editors. Harrison's Principles of Internal Medicine. $16^{\text {th }}$ ed. New York: McGraw-Hill; 2005. p. 2471-90.

17. Getaneh A, Medhin G, Shimelis T. Cryptosporidium and Strongyloides stercoralis infections among people with and without HIV infection and efficiency of diagnostic methods for Strongyloides in Yirgalem Hospital, southern Ethiopia. BMC Res Notes 2010;3:90.

18. De Vecchi E and Drago L. Lactobacillus sporogenes or Bacillus coagulans: Misidentification or mislabeling. Int J Probiotics Prebiotics 2006;1:3-10.

19. Huighebaert S, Awouters F, Tytgat GN. Racecadotril versus loperamide: Antidiarrheal research revisited. Dig Dis Sci 2003;48:239-50.

20. Jabs DA. Cytomegalovirus retinitis and the acquired immunodeficiency syndrome-Bench to bedside: LXVII Edward Jackson Memorial Lecture. Am J Ophthalmol 2011;151:198-216.

21. Shi $Y$, Lu H, He T, Yang Y, Liu L, Zhang R, et al. Prevalence and clinical management of cytomegalovirus retinitis in AIDS patients in Shanghai, China. BMC Infect Dis 2011;11:326. 
22. Patil AJ, Sharma A, Kenney MC, Kuppermann BD. Valganciclovir in the treatment of cytomegalovirus retinitis in HIV-infected patients. Clin Ophthalmol 2010;4:111-9.

23. Heiden D, Ford N, Wilson D, Rodriguez WR, Margolis T, Janssens B, et al. Cytomegalovirus retinitis: The neglected disease of the AIDS pandemic. PLoS Med 2007;4:e334.

24. Matsumura $Y$, Shindo $Y$, linuma $Y$, Yamamoto $M$, Shirano M, Matsushima A, et al. Clinical characteristics of Pneumocystis pneumonia in non-HIV patients and prognostic factors including microbiological genotypes. BMC Infect Dis 2011;11:76.

25. Ruan S, McKinley L, Zheng M, Rudner X, D'Souza A, Kolls JK, et al. Interleukin-12 and host defense against murine Pneumocystis pneumonia. Infect Immun 2008;76:2130-7.

26. Pozio E. Highly active antiretroviral therapy and opportunistic protozoan infections. Parassitologia 2004;46:89-93.

27. Pomarico L, Cerqueira DF, de Araujo Soares RM, de Souza IP, de Araujo Castro GF, Socransky S, et al. Associations among the use of highly active antiretroviral therapy, oral candidiasis, oral Candida species and salivary immunoglobulin A in HIV-infected children. Oral Surg Oral Med Oral Pathol Oral Radiol Endod 2009;108:203-10.

28. Foudraine NA, Weverling GJ, van Gool T, Roos MT, de Wolf F, Koopmans PP, et al. Improvement of chronic diarrhoea in patients with advanced HIV-1 infection during potent antiretroviral therapy. AIDS 1998;12:35-41.

29. Bini EJ, Cohen J. Impact of protease inhibitors on the outcome of human immunodeficiency virus-infected patients with chronic diarrhea. Am J Gastroenterol 1999;94:3553-9.

30. Walsh JC, Jones CD, Barnes EA, Gazzard BG, Mitchell SM. Increasing survival in AIDS patients with cytomegalovirus retinitis treated with combination antiretroviral therapy including HIV protease inhibitors. AIDS 1998;12:613-8.

31. Oliva J, Moreno S, Sanz J, Ribera E, Molina JA, Rubio R, et al. Coadministration of rifampin and nevirapine in HIV-infected patients with tuberculosis. AIDS 2003;17:637-8

32. Ribera E, Pou L, LopezRM, Crespo M, Falco V, Ocañal, etal. Pharmacokinetic interaction between nevirapine and rifampicin in HIV-infected patients with tuberculosis. J Acquir Immune Defic Syndr 2001;28:450-3.

How to cite this article: Kapadia JD, Desai CK, Dikshit RK, Solanki MN, Shah AN. A study of utilization pattern, efficacy and safety of drugs prescribed for opportunistic infections in Human Immunodeficiency Virus infected patients. Int J Med Public Health 2014;4:200-9.

Source of Support: Nil, Conflict of Interest: None declared. 